日植病報 $46: 150-158(1980)$

Ann. Phytopath. Soc. Japan $46: 150-158$ (1980)

\title{
A Comparison of DNA Base Compositions among Anastomosis Groups in Rhizoctonia solani Kühn
}

\author{
Shiro Kuninaga* and Ryozo Yokosawa* \\ 国永史朗*・横沢菱三*：菌系融合群を異にする Rhizoctonia solani \\ 菌の GC 含量比較
}

\begin{abstract}
Base composition of DNAs of 30 isolates of Rhizoctonia solani Kühn was compared. The relationships between the base composition of DNA and each anastomosis group or cultural type were investigated.

The range of guanine plus cytosine (GC) content of $R$. solani DNA was 40.9 to 49.3 mole $\%$, and its average was 45.3 mole \%. The GC contents of the isolates within each anastomosis group were almost same. Little difference of $\mathrm{GC}$ content was observed between the sasakii type (IA) and the web-blight type (IB) in AG-1. Furthermore GC contents of the rush type (IIIB) and the root rot type (IV) in AG-2-2, were quite similar. While a significant difference was observed between the potato type (IV) in AG-3 and the root rot type (IV).

AG-1 showed the highest GC content (avg. 48.8 mole \%) among all of the anastomosis groups, followed by AG-4 (avg. 47.3 mole \%), AG-3 (avg. 47.1 mole \%), AG-5 (avg. 45.2 mole \%), AG-2-2 (avg. 44.6 mole \%), AG-2-1 (avg. 43.7 mole \%), AG-6 (avg. 41.8 mole $\%$ ) and AG-BI (avg. 41.4 mole \%).

These results suggest that each anastomosis group must be regarded as a genetically independent unit.
\end{abstract}

(Received November 1, 1979)

\section{Introduction}

It has been well documented that Rhizoctonia solani Kühn involves physiologically, ${ }^{19,23)}$ biochemically, ${ }^{16)}$ serologically ${ }^{1)}$ and ecologically ${ }^{30,31)}$ different groups. Some researchers ${ }^{18}$, 20,21 ,22) have attempted to divide this fungus to some groups with anastomosis behaviours. Japanese isolates were divided into six anastomosis groups (AGs): AG-1 (sasakii type and web-blight type), AG-2-1 (winter crops type), AG-2-2 (rush type and root rot type), AG-3 (potato type), AG-4 (praticola type) and AG-518). Recently two new AGs, AG-6 and $A G-B I$, were obtained from non-cultivated soils ${ }^{10)}$. The suggestion has been made that the physiological and morphological similarity of isolates within the same AG must be greater than that among different $\mathrm{AGs}^{11,18,23)}$.

Determination of the base composition of deoxyribonucleic acid (DNA), expressed as mole percent of guanine plus cytosine (GC content), has been well established as one of

\footnotetext{
* Department of General Education, Higashi Nippon Gakuen University, Onbetsu, Hokkaido 088-01, Japan 東日本学園大学教養部
} 
the most useful approaches to bacterial taxonomy ${ }^{9,12,13,15)}$. However this method has scarecely been used for fungal taxonomy. DNAs of fungi were analyzed by Uryson \& Belozersky ${ }^{27)}$, Vanyushin et al. $^{28)}$ and by Storck. ${ }^{24)}$ Storck \& Alexopoulos ${ }^{26)}$ analyzed the DNAs of 322 species of fungi and suggested that there might be a relationship between the GC content of fungal DNA and taxonomic and phylogenetic data.

Of plant pathogenic fungi, GC content of Phytophthora infestans is the first report on the DNA composition ${ }^{6)}$. Recently Chang $\& \mathrm{Wu}^{3}$ ) have reported comparative $\mathrm{GC}$ contents of 63 isolates of $R$. solani.

Table 1. The isolates used

\begin{tabular}{|c|c|c|c|c|}
\hline Isolate & Source & $\begin{array}{c}\text { Geographic } \\
\text { origin }\end{array}$ & $\begin{array}{l}\text { Anastomosis } \\
\text { group }\end{array}$ & Cultural type \\
\hline R 71 & Rice, Sheath & Tochigi & $\left.A G-1^{2}\right)$ & IA, sasakii typeb) \\
\hline $\mathrm{CS}-\mathrm{Ka}$ & Rice, Sheath & Hokkaido & " & "I \\
\hline$A-10$ & Rice & Hiroshima & $" 1$ & $" \prime$ \\
\hline OO $1-7$ & Soil & Hokkaido & " & IB, web-blight type \\
\hline $\mathrm{K}-18$ & Sugar beet, Petiole & Hokkaido & $"$ & " \\
\hline SFBV-1 & Sugar beet, Seedling & Tochigi & $" \prime$ & $" 1$ \\
\hline R123 & Radish, Seedling & Aichi & AG--2-1 & II, winter crops type \\
\hline SHM 1-2 & Soil & Hokkaido & " & " \\
\hline RPS- -4 & Pea, Seedling & Gunma & $" 1$ & $" 1$ \\
\hline B 52 & Sugar beet, Petiole & Okayama & $A G-2-2$ & IIIB, rush type \\
\hline B 60 & Sugar beet, Petiole & Okayama & $"$ & "I \\
\hline C -112 & Mat rush, Stem & Kumamoto & $" 1$ & " \\
\hline R 88 & Soil & Kanagawa & $"$ & IV, root rot type \\
\hline BR-2 & Sugar beet, Root & Hokkaido & $" 1$ & $" 1$ \\
\hline 48 HDTN & Sugar beet, Root & Hokkaido & $" 1$ & $1 "$ \\
\hline ST 3-1 & Potato & & AG-3 & IV, potato type \\
\hline ST4-1 & Potato, Sclerotia & Hokkaido & " & " \\
\hline ST 6-3 & Potato, Sclerotia & Hokkaido & 11 & $" 1$ \\
\hline RR 5-2 & Sugar beet, Root & Hokkaido & $\mathrm{AG}-4$ & IIIA, praticola type \\
\hline Chr-3 & Chrysanthemum, Stem & Tochigi & " & "I \\
\hline R 101 & Cabbage, Seedling & Kanagawa & $" 1$ & $" \prime$ \\
\hline TE 1-5 & Soil & Hokkaido & AG-5 & \\
\hline R3P & Potato, Sclerotia & Hokkaido & " & \\
\hline $\mathrm{K}-7$ & Sugar beet & Hokkaido & $" 1$ & \\
\hline AT 2-1 & Soil & Hokkaido & AG-6 & \\
\hline HAM 1-1 & Soil & Hokkaido & "I & \\
\hline SO 2-1 & Soil & Hokkaido & " & \\
\hline $\mathrm{SH} \mathrm{1-2}$ & Soil & Hokkaido & AG-BI & \\
\hline KA 1-1 & Soil & Hokkaido & " & \\
\hline KO 1-1 & Soil & Hokkaido & " & \\
\hline
\end{tabular}

a) Anastomosis group (Ogoshi, 1976)

b) Cultural type (Watanabe \& Matsuda, 1966) 
To examine genetical and evolutional relationships among each anastomosis groups in $R$. solani, DNAs base compositions of their isolates were compared.

\section{Materials and Methods}

Isolates. Thirty isolates of $R$. solani selected from each anastomosis group ${ }^{10,18)}$ and cultural type ${ }^{31)}$ were used. The details of these isolates are given in Table 1.

Cultivation of fungi. The inoculum of each isolate was prepared by homogenizing a mycelial mat previously cultured on potato dextrose (PD) broth for $\mathbf{5}$ days. The mycelial homogenate was then inoculated on PD broth. After 5 days of incubation at $25 \mathrm{C}$, mycelial mats were collected and washed twice with a saline-EDTA solution $(0.15 \mathrm{M} \mathrm{NaCl}, 0.1 \mathrm{M}$ ethylenediaminetetraacetate, $\mathrm{pH} \mathrm{8.0),} \mathrm{and} \mathrm{were} \mathrm{used} \mathrm{for} \mathrm{DNA} \mathrm{isolation.}$

DNA extraction and purification. Extraction and purification diagram of $R$.

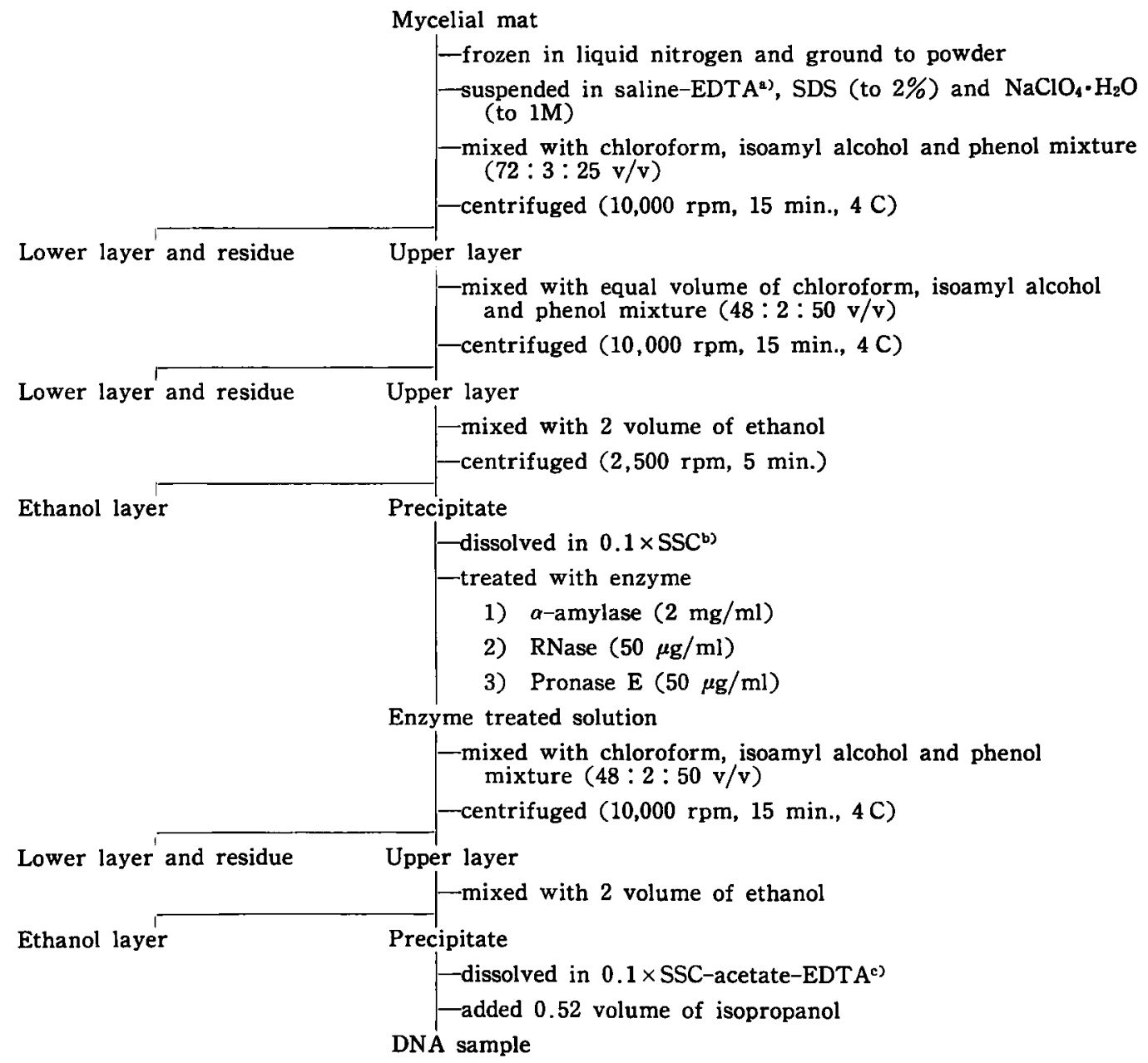

Fig. 1. Isolation procedure of $R$. solani DNA.

a) $0.15 \mathrm{M} \mathrm{NaCl}-0.1 \mathrm{M}$ EDTA (pH 8.0)

b) $0.015 \mathrm{M} \mathrm{NaCl}-0.0015 \mathrm{M}$ citrate ( $\mathrm{pH} 7.0$ )

c) 9 vols. of $0.015 \mathrm{M} \mathrm{NaCl}-0.0015 \mathrm{M}$ citrate plus 1 vol. of $3 \mathrm{M}$ acetate-0.001 $\mathrm{M}$ EDTA 
solani DNA is shown in Fig. 1. DNA was extracted from mycelium powder which was ground in liquid nitrogen ${ }^{2}$. The procedure used for DNA purification is a combination of the methods described by Cheng \& Sueoka ${ }^{5)}$, Villa $\&$ Storck $^{29)}$, and Marmur ${ }^{14)}$. $\alpha$-Amylase and pronase E (Kaken chemical, LTD) were used respectively for the removal of proteins and polysaccharides from a DNA sample. Finally purified DNA was obtained by using the isopropyl alcohol precipitation technique ${ }^{14)}$. The DNA usually appeared in fibrous form, and was collected by spooling onto a glass stirring rod.

Determination of DNA base composition. Base composition of DNA was determined by chemical analysis ${ }^{4}$. After hydrolysis of the DNA sample with $98-100 \%$ formic acid for 30 minutes at $175 \mathrm{C}$, DNA bases were separated by paper-chromatography using isopropyl alcohol-hydrochloride-water as a solvent system ${ }^{32,33)}$. Each spot detected

Table 2. Chemically analyzed base composition of $R$. solani DNA

\begin{tabular}{|c|c|c|c|c|c|c|}
\hline \multirow{2}{*}{ Isolate } & \multicolumn{4}{|c|}{ Base composition of DNA (mole \%) } & \multirow{2}{*}{$\frac{\text { Purine }}{\text { Pyrimidine }}$} & \multirow{2}{*}{$\begin{array}{l}\text { Adenine }+ \text { Thymine } \\
\text { Guanine + Cytosine }\end{array}$} \\
\hline & Adenine & Guanine & Cytosine & Thymine & & \\
\hline $\mathbf{R} 71$ & 25.5 & 24.3 & 25.0 & 25.2 & 0.99 & 1.03 \\
\hline $\mathrm{CS}-\mathrm{Ka}$ & 25.8 & 24.0 & 24.8 & 25.4 & 0.99 & 1.05 \\
\hline A-10 & 25.3 & 24.7 & 24.6 & 25.4 & 1.00 & 1.03 \\
\hline OO 1-7 & 25.8 & 23.6 & 24.4 & 26.2 & 0.98 & 1.08 \\
\hline $\mathrm{K}-18$ & 24.9 & 24.0 & 25.1 & 26.0 & 0.96 & 1.03 \\
\hline SFBV-1 & 25.6 & 24.0 & 24.5 & 25.9 & 0.98 & 1.06 \\
\hline R 123 & 27.1 & 22.6 & 22.7 & 27.6 & 0.99 & 1.21 \\
\hline SHM 1-2 & 28.8 & 21.3 & 21.5 & 28.4 & 1.00 & 1.34 \\
\hline RPS-4 & 28.8 & 21.7 & 21.4 & 28.1 & 1.02 & 1.32 \\
\hline В 52 & 27.4 & 22.6 & 22.3 & 27.7 & 1.00 & 1.23 \\
\hline B 60 & 27.5 & 22.0 & 22.0 & 28.5 & 0.98 & 1.27 \\
\hline C-112 & 27.4 & 22.4 & 22.2 & 28.0 & 0.99 & 1.24 \\
\hline R 88 & 27.3 & 22.1 & 23.2 & 27.4 & 0.98 & 1.21 \\
\hline BR-2 & 28.2 & 21.6 & 22.3 & 27.9 & 0.99 & 1.28 \\
\hline 48HDTN & 27.5 & 22.3 & 22.3 & 27.9 & 0.99 & 1.24 \\
\hline ST3-1 & 25.7 & 23.6 & 23.4 & 27.3 & 0.97 & 1.13 \\
\hline ST4-1 & 26.4 & 23.4 & 23.2 & 27.0 & 0.99 & 1.15 \\
\hline ST6-3 & 26.2 & 23.9 & 24.0 & 25.9 & 1.00 & 1.09 \\
\hline RR5-2 & 25.5 & 23.5 & 23.6 & 27.4 & 0.96 & 1.12 \\
\hline Chr-3 & 25.5 & 23.9 & 24.1 & 26.5 & 0.98 & 1.08 \\
\hline R 101 & 26.8 & 23.3 & 23.6 & 26.3 & 1.00 & 1.13 \\
\hline TE 1-5 & 27.2 & 22.9 & 22.6 & 27.3 & 1.00 & 1.20 \\
\hline R3P & 26.7 & 22.7 & 22.0 & 27.8 & 1.01 & 1.25 \\
\hline $\mathrm{K}-7$ & 27.8 & 22.4 & 22.0 & 27.8 & 1.01 & 1.25 \\
\hline AT 2-1 & 29.2 & 20.3 & 21.9 & 28.6 & 0.98 & 1.37 \\
\hline HAM 1-1 & 29.4 & 20.1 & 21.3 & 29.2 & 0.98 & 1.42 \\
\hline SO 2-1 & 29.0 & 20.8 & 21.0 & 29.2 & 0.99 & 1.39 \\
\hline SH 1-2 & 30.1 & 20.3 & 20.7 & 28.9 & 1.02 & 1.44 \\
\hline KA 1-1 & 29.6 & 20.7 & 21.6 & 28.1 & 1.01 & 1.36 \\
\hline KO 1-1 & 29.1 & 20.1 & 20.8 & 30.0 & 0.97 & 1.44 \\
\hline
\end{tabular}


with UV lamp was eluted with $0.01 \mathrm{~N}$ HC1. The eluted bases were identified, and the amount of each was determined from its ultraviolet absorption spectrum by use of a spectrophotometer (MPS-5000, Shimazu co. LTD).

\section{Results}

\section{Base composition of R. solani DNA}

Base composition of DNAs of $30 R$. solani isolates is shown in Table 2. The sum of the purine bases (adenine plus guanine) was close to the sum of the pyrimidine bases (cytosine plus thymine), so DNA structures obtained were considered as typical double strand. The ratio of adenine plus thymine (AT) to guanine plus cytosine (GC) of examined isolates was in the range of 1.03 to 1.44 .

GC contents of each anastomosis group and each cultural type

$R$. solani isolates were found to have a GC content ranging from 40.9 to 49.3 mole $\%$ (Table 3 ). The average GC content was 45.3 mole $\%$. Fig. 2 shows the range of GC content of each anastomosis group and cultural type. In all isolates of one anastomosis group or one cultural type, almost the same GC contents were shown. The isolates of AG-1 (sasakii type) showed the highest average GC content, followed by AG-4 (praticola type), AG-3 (potato type), AG-5, AG-2-2 (rush type and root rot type), AG-2-1 (winter crops type), AG-6 and AG-BI. Details of GC contents of each anastomosis group or cultural type were as follows :

AG-1 (IA, sasakii type and IB, web-blight type): $\mathrm{AG}-1$ showed a $\mathrm{GC}$ content ranging from 48.0 to 49.3 mole \% (average 48.8 mole \%). This group had the highest GC content among all anastomosis groups or cultural types. The average GC contents of the sasakii type and of the web-blight type were 49.1 and 48.5 mole $\%$, respectively. Both cultural types showed similar DNA base composition.

AG-2-1 (II, winter crops type): AG-2-1 had a GC content ranging from 42.8 to 45.3 mole \% (average 43.7 mole \%). The widest intragroup variation of GC content was observed in this group.

AG-2-2 (IIIB, rush type and IV, root rot type): AG-2-2 had a GC content ranging
Table 3. GC content of DNA preparations from $R$. solani

\begin{tabular}{|c|c|c|}
\hline $\begin{array}{l}\text { Anastomosis } \\
\text { group }\end{array}$ & Isolate & $\begin{array}{l}\text { Mole percent } \\
\text { guanine plus } \\
\text { cytosine }\end{array}$ \\
\hline \multirow{6}{*}{ AG-1 } & R 71 & 49.3 \\
\hline & CS-Ka & 48.8 \\
\hline & A-10 & 49.3 \\
\hline & OO 1-7 & 48.0 \\
\hline & $\mathrm{K}-18$ & 49.1 \\
\hline & SFBV-1 & 48.5 \\
\hline \multirow[t]{3}{*}{$A G-2-1$} & R 123 & 45.3 \\
\hline & SHM 1-2 & 42.8 \\
\hline & RPS-4 & 43.1 \\
\hline \multirow[t]{6}{*}{$A G-2-2$} & В 52 & 44.9 \\
\hline & B 60 & 44.0 \\
\hline & $\mathrm{C}-112$ & 44.6 \\
\hline & R 88 & 45.3 \\
\hline & BR-2 & 43.9 \\
\hline & 48HDTN & 44.6 \\
\hline \multirow[t]{3}{*}{$A G-3$} & ST3-1 & 47.0 \\
\hline & ST4-1 & 46.6 \\
\hline & ST6-3 & 47.9 \\
\hline \multirow[t]{3}{*}{$A G-4$} & RR5-2 & 47.1 \\
\hline & Chr-3 & 48.0 \\
\hline & R 101 & 46.9 \\
\hline \multirow[t]{3}{*}{ AG-5 } & TE 1-5 & 45.5 \\
\hline & R3P & 45.6 \\
\hline & $\mathrm{K}-7$ & 44.4 \\
\hline \multirow[t]{3}{*}{$A G-6$} & AT 2-1 & 42.2 \\
\hline & HAM 1-1 & 41.4 \\
\hline & SO 2-1 & 41.8 \\
\hline \multirow[t]{3}{*}{$A G-B I$} & SH 1-2 & 41.0 \\
\hline & KA 1-1 & 42.3 \\
\hline & KO 1-1 & 40.9 \\
\hline \multicolumn{2}{|c|}{ Range } & $40.9-49.3$ \\
\hline \multicolumn{2}{|c|}{ Average } & 45.3 \\
\hline
\end{tabular}




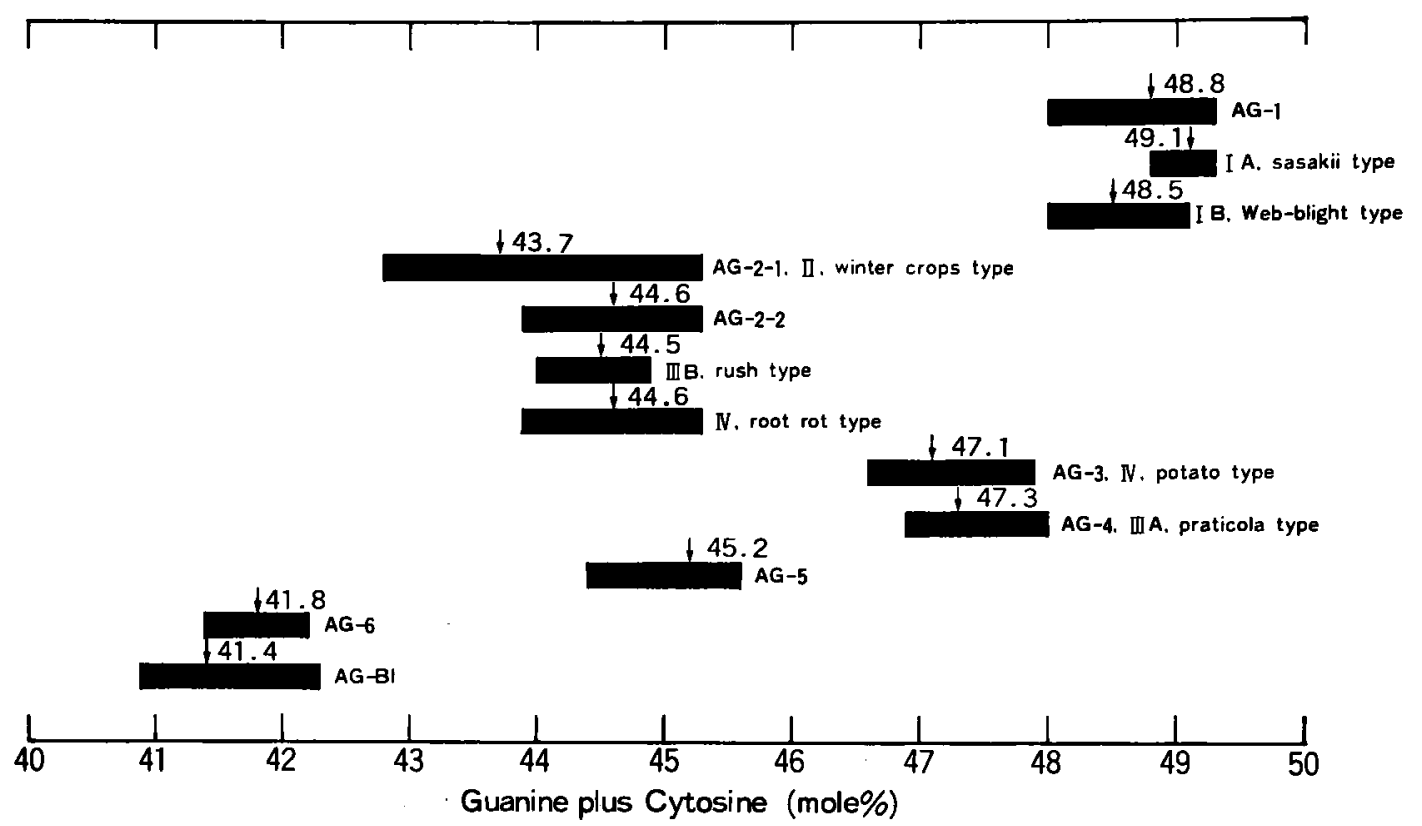

Fig. 2. Range of GC content values of anastomosis group and cultural type ot $R$. solani. Arrow indicates the average GC content of each group.

from 43.9 to 45.3 mole $\%$ (average 44.6 mole \%). No significant difference between AG2-1 and AG-2-2 was observed. The average GC contents of the rush type and of the root rot type were almost the same 44.5 and 44.6 mole \%, respectively.

AG-3 (IV, potato type): AG-3 had a GC content ranging from 46.6 to 47.9 mole $\%$ (average $47.1 \mathrm{~mole} \%$ ). The potato type and the root rot type, belongings of different anastomosis groups, were significantly different in GC contents.

AG-4 (IIIA, praticola type): AG-4 had a GC content ranging from 46.9 to 48.0 mole $\%$ (average 47.3 mole \%). The average GC content of this group was very close to AG-3 and ranked next to $A G-1$.

AG-5 : AG -5 had a GC content ranging from 44.4 to 45.6 mole \% (average 45.2 mole $\%$ ). The GC content of this group was close to that of AG-2-2.

AG-6: AG-6 had a GC content ranging from 41.4 to 42.2 mole \% (average 41.8 mole \%). Intragroup variation of this group was remarkably lower than others.

AG-BI : AG-BI had a GC content ranging from 40.9 to 42.3 mole \% (average 41.4 mole \%). The GC content of this group was the lowest among all anastomosis groups, but relatively close to that of $A G-6$.

\section{Discussion}

The difference of base sequence reflects on the diversity of phenotypic characteristics and GC content is similar in morphologically related organisms ${ }^{9,12,13,15)}$.

The GC content of DNA from species in Myxomycetes, Phycomycetes, Ascomycetes, and Basidiomycetes ranges from 34 to 63 mole $\%{ }^{24,27,28)}$. A difference between minimum and maximum GC content decreases from classes and subclasses to genera and species ${ }^{24,26)}$. 
In more than $80 \%$ of the species of tested fungi, GC content diversity was less than 5 mole ${ }^{26)}$. Fusarium ${ }^{8,26)}$ (eight species) and Chaetomium globosum ${ }^{26,28)}$, found to have variable characteristics within one clone or one species, showed a relatively narrow GC content range, contrary to expectation. But in a few cases, such as Thamnidium elegans and Helminthosporium speciferum, GC content variation within a species was more than 10 mole $\%{ }^{26)}$. From all evidence available at present, Storck \& Alexopoulos ${ }^{26)}$ stated that the intraspecific variation in GC content of fungus is generally less than 10 mole $\%$.

Using a spectrophotometric method ${ }^{7)}$, Chang $\& \mathrm{Wu}^{3)}$ reported that $\mathrm{GC}$ content of DNA from 63 isolates of $R$. solani ranged from 35.72 to 52.20 mole \%. In the present experiment, GC content range of 30 isolates was from 40.9 to 49.3 mole \%. As shown by these results, $R$. solani had a wide intraspecific variation in GC content, as compared with many other fungi.

In present study, GC contents of isolates within the same anastomosis group were quite similar, and we could not detect any difference of GC content between the sasakii type (IA) and the web-blight type (IB) in AG-1, or between the rush type (IIIB) and the root rot type (IV) in AG-2-2. These facts suggest good homogeneity among isolates within the same anastomosis group. This result corresponds to biochemical ${ }^{16)}$ and serological ${ }^{1)}$ studies of $R$. solani. Matsuyama et $\mathrm{al}^{16)}$. reported that non-specific esterase zymograms of same anastomosis group gave almost identical pattern. Adams \& Butler ${ }^{1)}$ have recently reported that the serologic groups corresponded to the anastomosis groups. Sherwood ${ }^{23)}$, and Ogoshi ${ }^{18}$ ) also described that ecological and morphological characteristics might be common to isolates of the same anastomosis group.

From these facts, we suggest that the wide intraspecific variation in GC content observed in $R$. solani is attributed only to a total variation of eight genetically independent anastomosis groups.

In this experiment, of eight anastomosis groups in $R$. solani, AG-1 (sasakii type) showed the highest GC content. It is well established that $\mathrm{AG}-1^{30,31)}$ have the physiologically and ecologically different characteristics and the pathogenic specificities in comparison with those of other anastomosis groups. Storck \& Alexopoulos ${ }^{26)}$ suggested that the evolution of fungi could have been accompanied by a progressive increase in the GC content of DNA. The increment in GC content accompanying evolution is also found among bacteria for the Actinomycetes ${ }^{9,26)}$ and also among intrageneric variations of Yeasts ${ }^{17,25,26)}$. Whether or not AG-1 is considered as the most evolutional group of other anastomosis groups, should be elucidated by further studies.

Our results showed close GC content values between different anastomosis groups, i. e., AG-3 and AG-4, AG-2-2 and AG-5, or AG-6 and AG-BI. But these two anastomosis groups are different in some ecological and physiological characteristics ${ }^{11,18,23)}$. Further studies will be conducted.

The authors wish to express deepest appreciation to Dr. A. Ogoshi, Hokkaido University, and Dr. T. Naiki, Gifu University, for kind supplying isolates of $R$. solani and for critical reviewing the manuscript.

\section{Literature cited}

1. Adams, G. C., Jr. and Butler, E. E. (1979). Phytopathology 69: 629-633. 
2. Brandt, E. E. and DeBusk, A. G. (1964). Neurospora Newsletter 6: 17.

3. Chang, S.-C. and Wu, L.-C. (1974). Memories of the College of Agriculture, National Taiwan Univ. 15: 22-26.

4. Chargaff, E. (1955). In the Nucleic Acids (Chargaff, E. and Davidson J. N. eds.), Vol. 1. Academic Press, New York and London. pp. 307-371.

5. Cheng, T. and Sueoka, N. (1964). Science 143: 1442-1443.

6. Clark, M. C., Lawrence, C. H., Page, O. T. and Hodgson, W. A. (1968). Can. J. Microbiol. 14: 482-483.

7. De Ley, J. (1967). Antonie van Leeuwenhoek 33: 203-208.

8. Dutta, S. K., Richman, N., Woodward, V. W. and Mandel, M.(1967). Genetics 57 : $719-727$.

9. Hill, L. R. (1966). J. Gen. Microbiol. 44 : 419-437.

10. Kuninaga, S., Yokosawa, R. and Ogoshi, A. (1978). Ann. Phytopath. Soc. Japan 44: 591-598.

11. Kuninaga, S., Yokosawa, R. and Ogoshi, A. (1979). Ibid. 45: 207-214.

12. Lee, K. Y., Wahl, R. and Barbu, E. (1956). Ann. Inst. Pasteur 91 : 212-224.

13. Mandel, M. (1969). Ann. Rev. Microbiol. 23 : 239-274.

14. Marmur, J. (1961). J. Mol. Biol. 3 : 208-218.

15. Marmur, J., Falkow, S. and Mandel, M. (1963). Ann. Rev. Microbiol. 17 : 329-372.

16. Matsuyama, N., Moromizato, Z., Ogoshi, A. and Wakimoto, S. (1978). Ann. Phytopath. Soc. Japan 44: 652-658.

17. Nakase, T. and Komagata, K. (1968). J. Gen. Appl. Microbiol. 14: 345-357.

18. Ogoshi, A. (1976). Bull. Natl. Inst. Agric. Sci. Series C. 30 : 1-63.

19. Ogoshi A. and Ui, T. (1979). Ann. Phytopath. Soc. Japan 45: 47-53.

20. Parmeter, J. R. Jr., Sherwood, R. T. and Platt, W. D. (1969). Phytopathology 59: 1270-1278.

21. Richter, H. and Schneider, R. (1953). Phytopath. Z. 20 : 165-226.

22. Schultz, H. (1936). Arb. Biol. Reichsanst. f. Land-und Forstw. (Berlin) 22: 1-44.

23. Sherwood, R. T. (1969). Phytopathology 59: 1924-1929.

24. Storck, R. (1966). J. Bacteriol. 91 : 227-230.

25. Storck, R., Alexopoulos, C. J. and Phaff, H. J. (1969). Ibid. 98: 1069-1072.

26. Storck, R. and Alexopoulos, C. J. (1970). Bacteriol. Rev. 34: 126-154.

27. Uryson, S. O. and Belozersky, A. N. (1960). Dokl. Akad. Nauk. SSSR. 133 : 708-710.

28. Vanyushin, B. F., Belozersky, A. N. and Bogdanova, S. L. (1960). Ibid. 134 : 1222-1225.

29. Villa, V. D. and Storck, R. (1968). J. Bacteriol. 96 : 184-190.

30. Watanabe, B. (1977). Ann. Phytopath. Soc. Japan 43: 240-242.

31. Watanabe, B. and Matsuda, A. (1966). Appointed Experiment (Plant Diseases and Insect Pests). No. 7, Agriculture, Forestry, and Fishery Research Council and Ibaraki Agric. Exp. Sta. pp. 131.

32. Wyatt, G. R. (1951). Biochem. J. 48: 584-590.

33. Wyatt, G. R. (1955). In the Nucleic Acids (Chargaff E. and Davidson, J. N. eds.), Vol. 1. Academic Press, New York and London. pp. 243-265.

和 文 摘 要

\title{
菌系融合群を異にする Rhizoctonia solani 菌のGC含量比較
}

\author{
国永史朗・横沢菱三
}

Rhizoctonia solani の同一菌系融合群内または培堆型内の菌怢の遺伝的類縁性を知る手段として, 菌体か らDNAを抽出し，その塩基組成を測定した。 $R$. solani 30菌株のDNAの GC (Guanine plus Cytosine) 含量は 40.9 49.3 mole \%の範讲にあり平均 45.3 mole \%であった。同一菌糸融合群内の菌株のGC含量は 相互に近い值を示した。また，培養型を異にしても同じ菌釆融合群に属すむの，すなわち AG-1の sasakii type と web-blight type の間，あるいはAG-2-2の rush type と root rot type の間でGC含量には大差 
が認められなかった。逆に同一培荃型とされ菌系融合群の異なるるの，すなわち root rot type (IV) と potato type (IV) の間で GC 含量は明らかに異なった。菌系融合群のうち，AG-1は最む高いGC含量（平 均 48.8 mole \%) を示し, 次いでAG-4 (平均 47.3 mole \%), AG-3 (平均47.1 mole \%), AG-5 (平均45.2 mole \%), AG-2-2 (平均 44.6 mole \%), AG-2-1 (平均 43.7 mole \%), AG-6 (平均 41.8 mole \%), AG-BI 平均 41.4 mole \%) であった。以上のことから $R$. solani の同一菌糸融合群内の菌株は，遗伝的に非常に近 緑であることが示唆された。 